\title{
Development of approach to improvement of urban traffic flow diagram
}

\author{
Andrey Burlutsky ${ }^{1, *}$, Galina Pushkareva ${ }^{1}$, and Elena Kirgisarova ${ }^{1}$ \\ ${ }^{1}$ Tomsk State University of Architecture and Building, 634003 Tomsk, Russia
}

\begin{abstract}
The result of generalized analysis of Russian and foreign studies focused on urban transportation systems demonstrate that the existing methods of forming schemes of passenger transport routes only partially account interaction of transport flows and urban highways. Usually, insufficient attention is paid to optimization criteria that allow performing comprehensive analysis of rationality of transport route schemes. It is defined that speed is one of the key optimization criteria for transport systems that accounts specific feature of traffic flow organization on a street network of a big city and its state with regard to the use of traffic. An approach to reasonable scheduling of route scheme reorganization was developed basing on the routing experience, it allows accounting the factors that defines technical state of a road network and characteristics of transport flows.
\end{abstract}

\section{Introduction}

The activities of a modern major city is determined by its infrastructure, one of the key elements of which is street network and passenger transport operation on its territory. High social significance of urban passenger transport shall be emphasized, it is implemented in providing freedom of movement for citizens and reducing commuting time.

Today's level of transport infrastructure development does not allow meeting transportation needs of the population completely. The primary reason for it is drop in the rates of construction, reconstruction and overhaul of transportation infrastructure objects. The acute transportation-related problems are observed in major cities and metropolises, planning schemes of which were designed long ago. In these conditions, insufficiently developed road and transport infrastructure results in actual commuting time exceeding the permissible threshold value $[1,2]$. This leads to violation of the basic principle of urban transport systems formulated by a French architect Le Corbusier as follows: "No city can grow faster than its transport does".

Due to the increase of citizens' economic activity that causes growth of their transport mobility, daily use of automobiles becomes more attractive. At the same time, passenger cars are characterized by low carrying capacity and significant traffic lane space occupied. This indicates inefficiency of using such passenger transport for stable and massive workrelated movements that occur in certain time periods. However, all citizens' transitions obviously cannot be managed by public transport alone. It shall be noted that passenger cars

\footnotetext{
* Corresponding author: abura124@yandex.ru
} 
have equal importance in organization of transportation, since they provide significant amount of cultural and social mobility of urban population [3].

Considerable growth of car ownership level peculiar to cities of Western Europe and the USA after the World War II provoked serious crisis processes accompanied by aggravation of transport situation. Back then, specialists realized that urban highways constructed before massive appearance of cars didn't comply with the traffic parameters. Further on, many American scientists confirmed the necessity to change the adopted European way of cities development that provides growth of public transport system [4-6].

According to the specialists' estimates [7, 8], Russia is more than 20 years behind the developed countries by the level of transport infrastructure development, repeating past mistakes of the western countries and facing the same problems. Project solutions currently designed in Russia mostly support interests of car owners who provide no more that $40 \%$ of the entire passenger traffic $[3,9]$.

Many researchers $[4,5,7,8,10-13]$ note that selection of reasonable route schemes is one of the most issues for organization of public transport operation. Commuting time within the city largely depends on level of route scheme quality. Therefore, route scheme shall be considered along with street and road network of the city.

Scientists all over the world deal with the issues of bus route schemes improvement starting with the 1930th. The key studies in the field of design of urban public transport system belong to A. Aleksandrov, L. Bronstein, A. Zilbertal, V. Larioniv, A. Polyakov, D. Samoilov. Development of scientifically proven methodologies for designing bus route schemes is studied in the works of B. Gerominus, D. Dzhumaev, M. Antoshvili, V. Buneev, G. Varelopulo, I. Spirin, E. Safronov, M. Khrushchev [3], F. Glik [5], S. Olkhovsky [11] and V. Yavorsky. Among foreign studies, special interest is caused by the issued of modeling of public transport network [14].

Analysis of the routing experience demonstrated that provision of the existing methods of optimal routing schemes design require clarification as they do not account technical parameters of urban streets and roads. For the above reasons, further development of approach to reforming th route scheme with the reference to the highway system operation is considered a relevant issue.

\section{Research methods}

Based on the analysis of requirements to operation of urban public transport which are presented in detail in scientific literature, the key principles of route schemes optimization were developed (Fig. 1) [9]. 


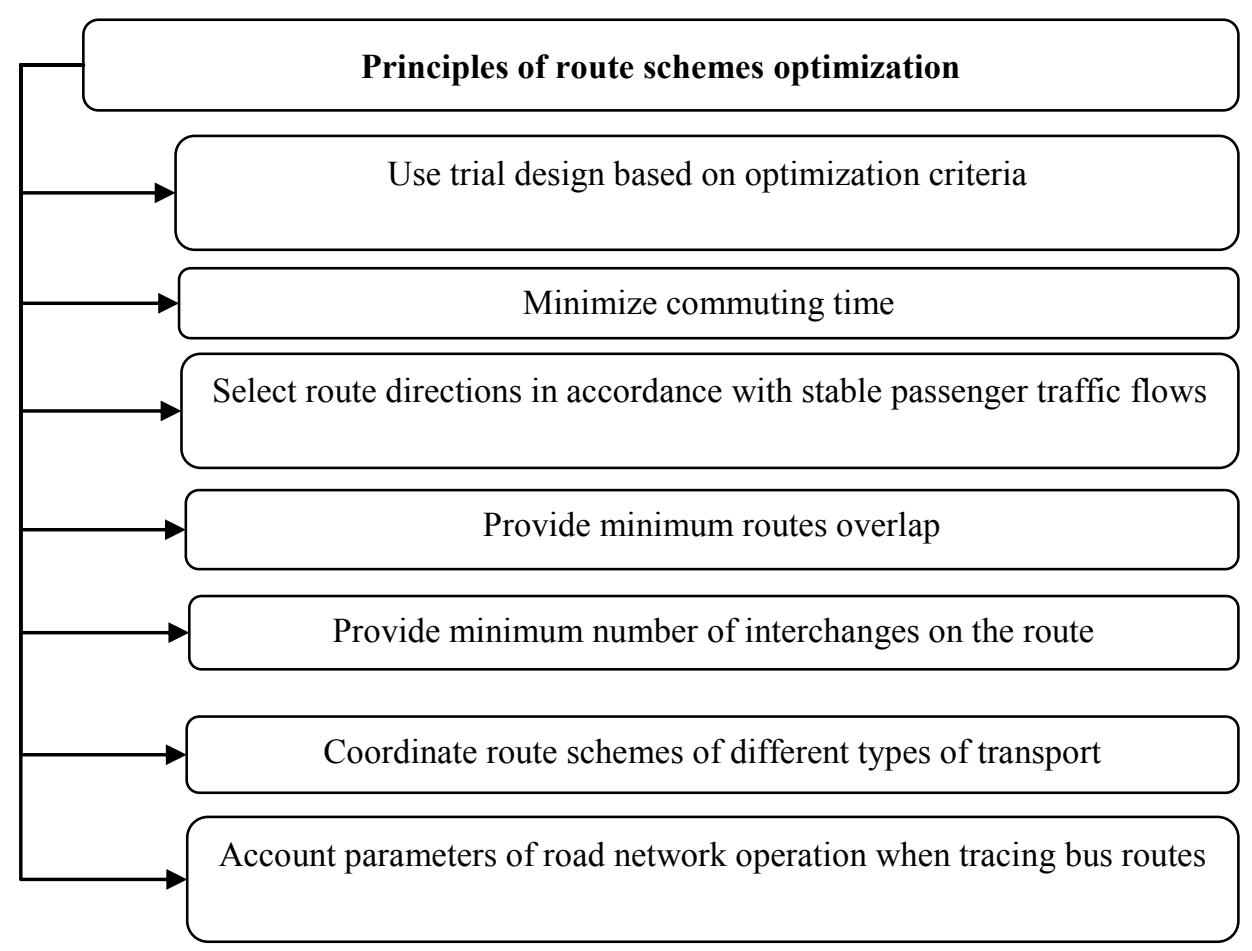

Fig. 1. Principles of route schemes optimization.

Representation of the set objective as a number of operational efficiency criteria is one of the key stages of studying a system of urban passenger transport. The most effective method enables searching solutions based on one crucial criterion with transition of the rest criteria in the category of limitations. In general form, it can be put as follows [9]:

$$
\left\{\begin{array}{c}
\mathrm{X} \rightarrow \text { extrem } \\
\mathrm{Y}_{1}^{\min }<\mathrm{Y}_{1}<\mathrm{Y}_{1}^{\max } \\
\quad \cdots \\
Y_{\mathrm{n}}^{\min }<\mathrm{Y}_{\mathrm{n}}<\mathrm{Y}_{\mathrm{n}}^{\max }
\end{array}\right.
$$

where $\mathrm{X}$ - the crucial criterion defined on the basis of expert evaluations;

$\mathrm{Y}$ - multitude of second tier criteria sufficient for complete description of the role of the studied object.

The optimization criteria for certain routes and route schemes accepted in the study are presented in Table 1. According to the majority of scientists, commuting time of citizens can be taken as a key optimality criterion. It should be mentioned that the standard for work-related commuting time are settled in the existing regulatory document [15].

Taking into account multicriterion nature of routing task, the approach to selecting the most rational solution shall be presented in the following form [9]: 
for route scheme

$$
\left\{\begin{array}{c}
\mathrm{t}_{\mathrm{av}} \rightarrow \min \\
\mathrm{K}_{r}^{\min }<\mathrm{K}_{\mathrm{r}}<\mathrm{K}_{\mathrm{r}}^{\max } \\
\delta_{r}^{\min }<\delta_{\mathrm{r}}<\delta_{\mathrm{r}}^{\max } \\
\mathrm{K}_{\mathrm{i}}^{\min }<\mathrm{K}_{\mathrm{i}}<\mathrm{K}_{\mathrm{i}}^{\max } \\
\mathrm{K}_{\mathrm{i} \text { pub }}^{\min }<\mathrm{K}_{\mathrm{i} \text { pub }}<\mathrm{K}_{\mathrm{i} \text { pub }}^{\max }
\end{array}\right.
$$

for certain route

$$
\left\{\begin{array}{c}
\mathrm{t}_{\mathrm{av}} \rightarrow \min \\
\mathrm{l}_{\min }<\mathrm{l}_{r}<\mathrm{l}_{\max } \\
\mathrm{K}_{\mathrm{i}}<\mathrm{K}_{\mathrm{i}}^{\max } \\
\mathrm{K}_{\mathrm{occ}}>\mathrm{K}_{\mathrm{occ}}^{\min } \\
\mathrm{I}_{\mathrm{rp}}<\mathrm{I}_{\max }
\end{array} .\right.
$$

\begin{tabular}{|c|c|c|}
\hline $\begin{array}{c}\text { Optimization } \\
\text { of } \\
\text { optimization }\end{array}$ & $\begin{array}{c}\text { Criterion } \\
\text { of optimization }\end{array}$ & $\begin{array}{l}\text { Rational limits of } \\
\text { criteria variation }\end{array}$ \\
\hline \multirow{5}{*}{$\begin{array}{l}\text { route } \\
\text { schemes }\end{array}$} & Average commuting time of a citizen $t_{a v}$ pub & $\mathrm{t}_{\mathrm{av} \mathrm{pub}}<40 \mathrm{~min}$ \\
\hline & Coefficient of interchanges $\mathrm{K}_{\mathrm{i}}$ & $1.15<\mathrm{K}_{\mathrm{i}}<1.30$ \\
\hline & Route coefficient $\mathrm{K}_{\mathrm{r}}$ & $2.0<\mathrm{K}_{\mathrm{r}}<3.0$ \\
\hline & Density $\mathrm{RN} \delta_{\mathrm{r}}$ & $1.5<\delta_{\mathrm{r}}<2.5$ \\
\hline & Coefficient of indirectness of traffic on a route network $K_{i \text { pub }}$ & $\mathrm{K}_{\mathrm{i} \text { pub }}<1.25$ \\
\hline \multirow{5}{*}{$\begin{array}{l}\text { bus } \\
\text { route }\end{array}$} & Average commuting time of a citizen $t_{a v} R T$ & - \\
\hline & Route length $1_{\mathrm{r}}$ & $\begin{array}{l}\text { regular } 15-30 \mathrm{~km} \\
\text { circular up to } 40 \mathrm{~km}\end{array}$ \\
\hline & Coefficient of available places occupancy $K_{o c c}$ & $\mathrm{~K}_{\mathrm{occ}}>0.5$ \\
\hline & Road pavement condition index $\mathrm{I}_{\mathrm{rp}}$ & $\mathrm{I}_{\mathrm{rp}}<3.0$ \\
\hline & Coefficient of indirectness of traffic on a route $K_{r}$ & $\mathrm{~K}_{\mathrm{r}}<1.25$ \\
\hline
\end{tabular}

Table 1. Optimization criteria for passenger transport route schemes.

Among the existing approaches to improving current route scheme the method of successive approximations to the optimum variant studied by F. Glik [5] should be noted. This approach has been developed in the works of S. Olkhovsky [11] and V. Yavorsky. They proposed more detailed dependences and algorithms that account a number of additional criteria when correcting the route network. These ideas were taken as a basis of the method [9] proposed in this paper.

The studied method is based on the analysis of the mobility plan for transportations that are not served by routes included in initial basic frame. Next step in the design of a new prospect route consists in selection of its foundation that corresponds to the most straight chain from the table of unimplemented connections with the highest value of passenger flow. Further actions include building up the considered foundation by adding the most suitable sections. All connections that partially overlap with the route foundation are considered, later they become elements for building several variants of superposed chains. By building-up connections to the initial chain one successively moving towards the supposed destination points. The process of building-up connections is repeated for each superposed chain which shall now be considered as a new route foundation. Based on the obtained tree of chains a set of variants of the designed route is formed (Fig. 2). As a result of directed search the mot reasonable variant which accounts optimization criteria is selected (Table 1), later is will be included in the rational route scheme. 

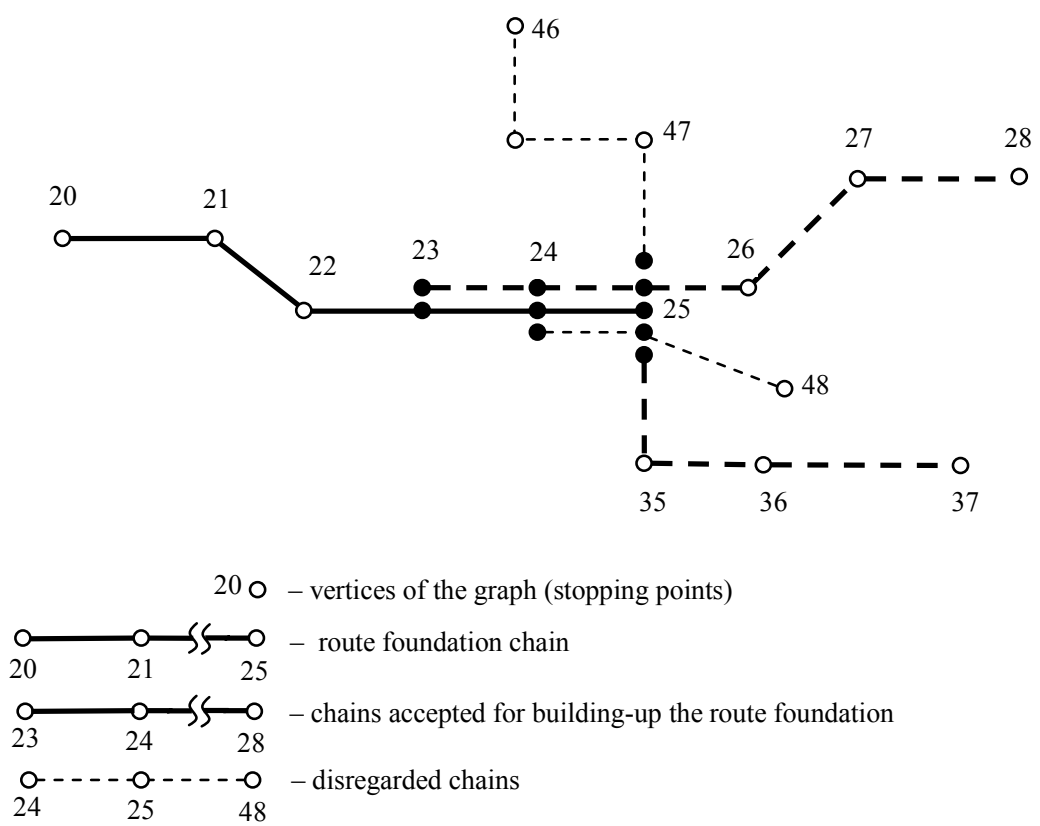

Fig. 2. Formation of variants of superposed chains.

The most rational variant of the studied route is determined in accordance with the adopted optimality criterion, among which are: average commuting time of a citizen $t_{a v}$, route length $1_{r}$, coefficient of indirectness of traffic on a route network $K_{i \text { pub}}$, Coefficient of available places occupancy $\mathrm{K}_{\mathrm{occ}}$. The procedure of inclusion on the initial frame of a new route is repeated until all possible transportations are implemented. The desired number of interchanges between the disconnected districts shall not be more than 1 . The process of designing a new route scheme is considered complete in case it fully complies with all the required conditions.

\section{Results}

Due to using combined analysis and directed variants selection it is possible to obtain a single route scheme variant, the parameters of which are close to that of the optimum variant. Formation of various route scheme variants can be based on alternative scenarios of urban transport network development. The most preferable route scheme variant is selected on the basis of the above optimality criteria. Commuting time of citizens is considered the most important criterion.

The main stages of route formation, as well as building-up of a rational route scheme with the account of highway network development are presented in Figures 3-4. 
From the mobility plan for unimplemented transitions an element that corresponds to the highest value of passenger flow is chosen.

The foundation of the designed route is based on the accepted chain.

All possible combinations of the number of destinations on the opposite ends of the foundation are considered, then a subset of the designed route variants is formed.

The optimality criteria are calculated for each of the route variants.

After that, the most rational route variant is chosen for further inclusion in the route scheme

Fig. 3. Succession of actions of passenger route design with the account of technical condition of the road and street network of a city.

A mobility plan of work-related transitions between the distinguished transport districts of a city is developed for a certain time period.

The initial frame of route scheme (basic variant) is built, mostly using routes that do not require correction.

By successive inclusion of new routes in the initial frame, variant of the route scheme that satisfies optimality criteria is developed.

Scenarios of improving efficiency of urban road network operation is developed by considering measures of various complexity and capital capacity.

Following the scenarios of road network development the route scheme variants are formed.

Based on evaluation of economic efficiency the most rational variant for developing road network and route scheme for passenger transport is selected.

Fig. 4. Succession of actions of passenger route design with the account of improvement of operational parameters of the road and street network of a city. 


\section{Conclusion}

Taking into account the accumulated routing experience, the approach to improvement of bus route scheme for a big city is developed in relation with operational condition of road and street network. Compared to the previously designed methods, the proposed approach accounts optimality criteria that allow comprehensive evaluation of route scheme efficiency. The essence of the approach consists in connecting individual sections of transport network and successive designing of competing route variants, one of which will then be included in the rational route scheme. At the final stage of the proposed algorithm alternative variants of rational route schemes are developed on the basis of scenarios for urban transport infrastructure development. This method will ensure increase in the traffic flow movement speed and as a result decrease in indirect commuting time. Further research will be focused on specification of dependences and calculation algorithm for movement speed of various types of passenger transport. Besides, further studies will suggest more complete account of factors that determine operational condition of road and street network, and parameters of transport flows, as well as their combination.

\section{References}

1. V.M. Buneev, V.I. Novoselov, N.N. Putilova, Jeffektivnost' gorodskogo passazhirskogo transporta: metody ocenki i obosnovanija [Urban passenger transport efficiency: evaluation and substantiation methods] (NGAVT, Novosibirsk, 2008). (in Russian)

2. I.S. Efremov, Teorija gorodskih passazhirskih perevozok [Theory of urban passenger transportations] (Vysshaya Shkola Publ., Moscow, 1980). (in Russian)

3. M.V. Khrushchev, Metody obshhej i lokal'noj marshrutizacii avtobusnogo transporta $v$ gorodah [Methods of general and local routing of urban bus transport] (GUU Publ., Moscow, 1999). (in Russian)

4. Vukan R. Vuchic, Transport v gorodah, udobnyh dlja zhizni [Transportation for livable cities] (Territorija budushhego, Moscow, 2011). (in Russian)

5. F.G. Glik, Interaktivnoe konstruirovanie marshrutnoj sistemy gorodskogo passazhirskogo transporta [Interactive design of route system of urban passenger transport] (Budivel'nik, Kiev, 1987). (in Russian)

6. A.A. Burlutsky, V.I. Korenev, U.U. Guseva, Vestnik of TSUAB, 1 (2018). (in Russian)

7. M.R. Yakimov, U.V. Trofimenko, Transportnoe planirovanie: formirovanie jeffektivnyh transportnyh sistem krupnyh gorodov [Transport planning: building efficient transport systems for major cities] (Logos Publ., Moscow, 2013). (in Russian)

8. A.Y. Mikhailov, I.M. Golovnykh, Sovremennye tendencii proektirovanija $i$ rekonstrukcii ulichno-dorozhnoj seti gorodov [Modern trends in design and reconstruction of urban road and street networks] (Nauka Publ., Novosibirsk, 2004). (in Russian)

9. A.A. Burlutsky, Obespechenie jeffektivnosti funkcionirovanija dorozhnoj seti krupnogo goroda na osnove ucheta ee vzaimodejstvija s potokami passazhirskogo transporta (na primere g. Tomska) [Ensuring operational efficiency of road networks in major cities based on accounting its interaction with passenger transport flows, example of Tomsk] (Tomsk, 2015). (in Russian)

10. M. Vol, B. Martin, Analiz transportnyh sistem [Analysis of transport systems] (Transport Publ., Moscow, 1981). (in Russian) 
11. S.Y. Olkhovsky, Modelirovanie funkcionirovanija i razvitija marshrutizirovannyh sistem gorodskogo passazhirskogo transporta [Modeling of operation and development of route schemes for urban passenger transport] (SIBADI Publ., Omsk, 2001) (in Russian)

12. V.U. Renkin, P. Klafi, S. Khalbert, Avtomobil'nye perevozki i organizacija dorozhnogo dvizhenija [Automobile transportation and organization of traffic] (Transport Publ., Moscow, 1981). (in Russian)

13. S.A. Vaksman, N.M. Gerasimov, I.A. Slepukhina, Informacionnye tehnologii v upravlenii gorodskim obshhestvennym passazhirskim transportom: monografija [Information technologies in urban public transport management: monograph] (Yekaterinburg, 2012). (in Russian)

14. S. Dimitrov, A. Ceder, S. Chowdhury, M. Monot, Transportation Planning and Technology, Vol. 40 (5), 592-610 (2017).

15. SP 42.13330.2011 Gradostroitel'stvo. Planirovka i zastrojka gorodskih i sel'skih poselenij. Aktualizirovannaja redakcija SNiP [Urban development. Planning and development of urban and rural areas. Revised edition of SNiP 2.07.01-89* (Moscow, 2011). (in Russian) 